ISSN 1392-3196 / e-ISSN 2335-8947

Zemdirbyste-Agriculture, vol. 102, No. 2 (2015), p. 167-176

DOI $10.13080 /$ z-a.2015.102.022

\title{
Evaluation of red clover (Trifolium pratense L.) resistance to Sclerotinia crown and root rot (Sclerotinia trifoliorum) in the laboratory and field conditions
}

\author{
Jovita MIKALIŪNIENĖ, Nijolè LEMEŽIENĖ, Vida DANYTĖ, Skaidrė SUPRONIENĖ \\ Institute of Agriculture, Lithuanian Research Centre for Agriculture and Forestry \\ Instituto 1, Akademija, Kedainiai distr., Lithuania \\ E-mail: jovita.bukauskaite@1zi.lt
}

\begin{abstract}
Red clover (Trifolium pratense L.) is very productive in the first two years of harvest but afterwards it tends to thin out dramatically and finally die. In Lithuania, the main disease causing this problem is Sclerotinia crown and root rot (Sclerotinia trifoliorum Eriks.). The present study was aimed to determine red clover resistance to Sclerotinia crown and root rot in the laboratory and field conditions. Investigations were carried out at Institute of Agriculture, Lithuanian Research Centre for Agriculture and Forestry. Resistance of red clover varieties and breeding lines to Sclerotinia crown and root rot was investigated in 2012-2014 in the field under natural and artificial infection conditions. Diploid (43: 20 varieties, 20 breeding lines, 2 wild ecotypes and 1 semiwild ecotype) and tetraploid (41: 24 varieties and 17 breeding lines) red clover was investigated. In the laboratory experiment, red clover seeds were treated with oxalic acid which is the main toxin of Sclerotinia spp. This experiment enabled us to evaluate seedling resistance to Sclerotinia crown and root rot. The same varieties and breeding lines as in the field experiment were investigated. The seedlings were treated with $0,5,7.5,10,15,20$ and $30 \mathrm{mM}$ oxalic acid concentrations. The most resistant varieties were found to be 'Kaive', 'Kvarta', 'Arimaičiai', 'Skriveru tetra', 'Van', 'Ostro', 'Radviliai' and 'Jogeva 433', and breeding lines Nos. 2102, 1582, 2190, 2087 and 2739. The most sensitive varieties were 'Sara', 'Sabtoron', 'Britta', 'Triton' and 'Astra', and breeding lines Nos. 2297, 2268, 2093, 2296, 2300 and 2298.
\end{abstract}

Key words: oxalic acid, resistance, Sclerotinia trifoliorum, Trifolium pratense.

\section{Introduction}

Red clover (Trifolium pratense L.) is an important forage legume that is widely cultivated in Europe because it is a valuable nitrogen-fixing component of leys, has beneficial effects on soil structure, and is an appreciated component of livestock diets (Öhberg et al., 2008). Red clover is a perennial forage legume of limited persistence, mainly used for cutting in grass-clover leys 2-4 years of duration, but also occurs naturally in permanent grassland.

Among the forage legumes, in terms of seed produced and marketed worldwide, and in numbers of cultivars available, red clover ranks second after alfalfa (Medicago sativa L.) but still higher than white clover (Trifolium repens $\mathrm{L}$.), although the latter has been gaining importance in the last decades (Boller et al., 2010).

However, red clover is infected by several fungal pathogens affecting its growth, persistence and overwintering capacity (Wallenhammar et al., 2006). One of the most destructive diseases is Sclerotinia crown and root rot, which is caused by the fungal pathogen Sclerotinia trifoliorum Erikson. The pathogen infects plants in the autumn and develops in the plant under snow cover during the winter. The disease symptoms rapidly appear on the plant once temperatures rise and the snow melts (Klimenko et al., 2010). In late summer and autumn apothecia develop from soil-borne sclerotia. Ascospores are released and cause necrotic spots on stems and leaves. These local infections do not develop further until the plants are subjected to weather conditions favourable for the fungus, between late autumn and early spring. Then the fungus starts to grow systemically through the petioles and stems into the plants' crowns, and eventually into their taproots (Öhberg et al., 2008). Furthermore, infection may also spread to other plants by means of mycelial growth, thus creating patches of dead plants in the field. In spring, infected plants are covered by slightly grey mycelia, with black sclerotia forming in dead plant tissues at soil level, or in soil close to dead plants. Sclerotia are well adapted for survival and can retain viability in soil for several years (Williams, Western, 1965; Öhberg et al., 2008).

Sclerotinia crown and root rot has been investigated for a long time and the investigations were comprehensive. Various infection backgrounds, methods of inoculation and various stages of development were explored (Svirskis, 1972; Dixon, Doodson, 1974; Marum 
et al., 1994; Delclos et al., 1997; Pokorny et al., 2003; Dabkevičienè, Dabkevičius, 2005; Öhberg et al., 2008). Svirskis (1972) investigated red clover and alfalfa varieties and breeding lines for resistance and survival under natural conditions and artificial inoculation, selected varieties, breeding lines and separated individuals for further breeding, defined some biological characteristics of Sclerotinia crown and root rot and fungus of Fusarium genus. Dixon and Doodson (1974), Marum et al. (1994), Delclos et al. (1997) and Pokorny et al. (2003) investigated various inoculation methods in the laboratory and fields conditions. Dabkevičiene and Dabkevičius (2005) investigated resistance of artificially inoculated wild red clover populations. Öhberg et al. (2008) carried out the investigation in North and South Sweden, where 15 red clover varieties were tested in the field conditions.

In Lithuania, Sclerotinia crown and root rot causes big losses of red clover foliage and seeds (Vilčinskas, Dabkevičienė, 2009). In Lithuania, the first investigations on red clover resistance to Sclerotinia crown and root rot were performed in 1958 (Žemaitienè, 1962). Žemaitienè (1962) inoculated various red clover varieties by pure Sclerotinia crown and root rot culture in a greenhouse. Бразаускене (1985) collected Sclerotinia crown and root rot material from red and white clover, separated 30 strains from it, evaluated their aggressiveness and possibilities to mix them for inoculum preparation. She compared different methods of evaluation of white clover breeding material resistance to Sclerotinia crown and root rot and found that for comparison of resistance and selection of resistant individuals direct and steppedup methods are the most suitable.

Most investigations were oriented towards varietal resistance estimation, but few of them were aimed to create a method for selection of resistant individuals during short time. In literature, there is little information about investigations with oxalic acid, which is the main toxin of Sclerotinia crown and root rot. Jančys and Vyšniauskienè (2002) carried out investigations with red clover and Liatukienè et al. (2012), to a greater extent, with alfalfa. The advantage of this method is the possibility of selection of resistant individuals during germination which lasts only a few days. It is easy to select a required percent of resistant plants from whole material by choosing the most suitable oxalic acid concentration. The investigations done with red clover and alfalfa according to this method showed good differentiation. Sensitive to Sclerotinia crown and root rot red clover varieties more distinctly responded to oxalic acid (Jančys, Vyšniauskienè, 2002; Liatukienè et al., 2012).

It is necessary to use fungicides to prevent Sclerotinia crown and root rot damage in red clover seed crops. Another, more effective way is choice of the right variety. The currently available varieties are productive and of good nutritional quality, but they produce insufficient seed yield, are moderately resistant to frost and insufficiently resistant to diseases (Gaurilčikienè, Staniulis, 2006).
Our study was designed to determine red clover resistance to Sclerotinia crown and root rot in the laboratory and field conditions.

\section{Material and methods}

Field experiment. Investigations were carried out at Institute of Agriculture, Lithuanian Research Centre for Agriculture and Forestry. Resistance of red clover varieties and breeding lines to Sclerotinia crown and root rot was investigated in 2012-2014 in the natural field conditions and using inoculation by sclerotiums of Sclerotinia trifoliorum Eriks. Diploid (43: 20 varieties, 20 breeding lines, 2 wild ecotypes and 1 semiwild ecotype) and tetraploid (41: 24 varieties and 17 breeding lines) red clover was investigated. The red clover genetic collection was established on a calcaric shallow gleyic Endocalcari-Epihypogleyic Cambisol (CMg-p-w-can) light loam. The collection was sown on the $8^{\text {th }}$ of June in 2012. Each red clover variety and breeding line was sown in two $5 \mathrm{~m}$ long rows in three replications. The distance between the rows of accessions was $0.5 \mathrm{~m}$; the distance between accessions was $1.0 \mathrm{~m}$. Interrows were applied with glyphosate using a hand sprayer. Sclerotinia crown and root rot damage in red clover crop was evaluated in spring in 2013 and 2014 after resumption of vegetation using a 1-9 score scale and was calculated to percent: 1 score $-0 \%, 2$ scores $-0.1 \%, 3$ scores $-1 \%, 4$ scores $5 \%, 5$ scores $-10 \%, 6$ scores $-20 \%, 7$ scores $-40 \%, 8$ scores $-60 \%$, 9 scores $-80 \%$ (Hartung, Piepho, 2007; Poland, Nelson, 2011).

Evaluation of resistance to Sclerotinia trifoliorum. Sclerotinia crown and root rot sclerotia were collected in the spring of 2012 from the crowns of dead red clover plants. They were sterilized in a solution of 5\% sodium hypochlorite and after that in $70 \%$ alcohol and washed with sterile water. After sterilization, sclerotia were placed on $2 \%$ agar medium and kept till the begging of mycelium growth. Actively growing isolates without other fungus and bacteria infection were selected. The mycelium was transferred on to the potato dextrose agar medium $\left(40 \mathrm{~g} \mathrm{l}^{-1}\right)$. The mycelium was grown and the cultures were kept in the dark at $20^{\circ} \mathrm{C}$ temperature. Fresh mycelium was used for investigation. When the mycelium was grown up, its surface was shaved off, put to water, shook up, filtrated and diluted till the required concentration (10000 spores $\left.\mathrm{ml}^{-1}\right)$. This solution was used for artificial inoculation of red clover. Spray application was done in October 2012 (Marum et al., 1994; Kanbe et al., 2002; Yli-Mattila et al., 2009).

Evaluation of resistance to oxalic acid. Red clover resistance to oxalic acid was evaluated as percent of germinated seeds using adapted method used in the researches of Rowe (1993), Jančys and Vyšniauskienè (2002) and Liatukienė et al. (2012). Seeds were scarified and surface sterilized in solution of $5 \%$ sodium hypochlorite for $15 \mathrm{~min}$ and rinsed three times in distilled water. Fifty sterilized seeds were placed in one plastic Petri plate (diameter $9 \mathrm{~cm}$ ) on filter paper moistened with $5 \mathrm{ml}$ of water solution of oxalic acid. Three replications 
were used for each clover entry per one concentration of oxalic acid. The seven concentrations of oxalic acid used were: $0,5,7.5,10,15,20$ and $30 \mathrm{mM}$. Petri plates with seeds were maintained in the dark at $20^{\circ} \mathrm{C}$ for seven days. Germinated seeds with actively growing roots were counted as resistant. Relative percent of germination was calculated for detailed analysis of clover accessions' reaction to oxalic acid. Percent of germinated seeds in $0 \mathrm{mM}$ solution of oxalic acid was equated to $100 \%$. Relative percent of germinated seeds in other concentrations was calculated as:

$$
\mathrm{RG}=\left(\mathrm{GS}_{\mathrm{OAx}} / \mathrm{GS}_{\mathrm{OA} 0}\right) \times 100,
$$

where $\mathrm{RG}$ is the relative percent of germinated seeds, $\mathrm{GS}_{\mathrm{OAx}}$ - the germinated seeds \% in corresponding oxalic acid concentration, $\mathrm{GS}_{\mathrm{OA} 0}$ - the germinated seeds $\%$ in oxalic acid concentration $0 \mathrm{mM}$ (Liatukienè et al., 2012).

Meteorological conditions. The summer of 2012 was warm, rainy and windy. There was a sufficient amount of moisture in the soil for red clover germination and further development. The autumn was warm, rainy and windy. The average air temperature was $1.4^{\circ} \mathrm{C}$ higher compared with the multiannual average, and precipitation was $132 \%$ of the multiannual average. The winter of 2012-2013 was early and long with a permanent snow cover and long soil freeze. December was cold, windy and with a lot of snow. The spring was late and short. In May, the weather was hot, similar to summer's weather. It was favourable for perennial grass growth. The summer was warm and with a fluctuating amount of precipitation. The autumn was warm, dry and long.

In the winter 2013-2014 the snow cover appeared only on the $13^{\text {th }}$ of January and melted on the $8^{\text {th }}$ of February. The weather in January was unusually warm, rainy and cloudy. The temperature in February was $4.7^{\circ} \mathrm{C}$ higher compared with the multiannual average. Foggy and windy weather prevailed. Such weather conditions favoured Sclerotinia crown and root rot development.

Statistical analysis. The research data were processed by the analysis of variance (Tarakanovas, Raudonius, 2003).

\section{Result and discussion}

Disease resistance is one of the most important traits of a good red clover variety. In our investigation, 84 genotypes of various origin were investigated for resistance to Sclerotinia crown and root rot (Sclerotinia trifoliorum Eriks.), which is the main disease of red clover. It occurs in the regions with cold winters, such as Lithuania. Resistance of red clover to $S$. trifoliorum depends on pathogen aggressiveness, plant genotype, phenotype (late or medium-late flowering type) and other local environmental abiotic and biotic factors (Öhberg et al., 2005; 2008). The development of clover crown and root rot depends heavily on the weather conditions. Favourable conditions - humid autumn and a warm, humid winter with short periods of frost - can lead to complete destruction of crops (Marum et al., 1994). In our investigation, the average of damaged red clover plants was more than three times lower in 2013 compared with 2014. In 2013 it was 7.8\% and in 2014 it was as high as $24.9 \%$ (Table 1). More favourable weather conditions for development of rot infection in 2014 probably influenced the differences between years. As expected, higher damage was in the artificially infected field. In 2013, it was $11.0 \%$ compared with $4.7 \%$ in the uninfected field and in 2014 it was $30.7 \%$ and $19.1 \%$, respectively.

Table 1. Percent of damaged red clover plants

\begin{tabular}{|c|c|c|c|c|c|c|c|c|c|c|c|c|}
\hline \multirow{2}{*}{$\begin{array}{l}\text { Field } \\
\text { type }\end{array}$} & \multicolumn{4}{|c|}{2013} & \multicolumn{4}{|c|}{2014} & \multicolumn{4}{|c|}{ 2013-2014 } \\
\hline & $2 n$ & $4 n$ & average & $\mathrm{LSD}_{05}$ & $2 n$ & $4 n$ & average & $\mathrm{LSD}_{05}$ & $2 n$ & $4 n$ & average & $\mathrm{LSD}_{05}$ \\
\hline Uninfected field & 5.3 & 4.0 & 4.7 & 1.25 & 18.5 & 19.6 & 19.1 & 2.72 & 11.9 & 11.8 & 11.9 & 1.96 \\
\hline Infected field & 14.7 & 7.1 & 11.0 & 3.03 & 30.2 & 31.2 & 30.7 & 3.14 & 22.5 & 19.2 & 20.9 & 2.80 \\
\hline $\mathrm{LSD}_{05}$ & 2.66 & 1.85 & 1.70 & - & 2.61 & 3.26 & 2.07 & - & 2.24 & 2.59 & 1.71 & - \\
\hline
\end{tabular}

There was a significant difference in the percentage of damaged plants between diploid and tetraploid red clover in 2013, when the infection was not high. In 2014, the infection was 4-5 times higher and there was no significant difference between the percentage of damaged diploid and tetraploid plants. Some authors maintain that tetraploid red clover varieties are more resistant to Sclerotinia crown and root rot compared with diploid varieties (Dijkstra, 1964; Raynal, 1985), others maintain that ploidy does not have any influence on the resistance to this disease (Ortega et al., 1997; Öhberg et al., 2005).

Weather conditions and infection level by Sclerotinia crown and root rot have strong influence on red clover wintering (Sprainaitis, 2000). The weather conditions were favourable for the spread of Sclerotinia crown and root rot in the autumn of 2012, which was long, warm and with a lot of rain. The soil was frozen and snow cover lasted all winter. In the spring of 2013, the breeding lines and varieties of red clover in artificially uninfected field were damaged by Sclerotinia crown and root rot from $0 \%$ to $15.8 \%$ (Table 2). Varieties 'Vesna', 'Kvarta', 'Divaja', 'Skriveru tetra' and 'Jogeva 205', and breeding lines Nos. 2096, 2300, 2301, 2190 and 1589 were not damaged $(0 \%)$ by Sclerotinia crown and root rot. Low resistance to the disease was shown for the varieties 'Amos', 'Vyčiai', 'Sprint', 'Spurt' and 'Astra'. They were damaged by $10.8-12.5 \%$. The least resistant breeding lines Nos. 2108, 2297, 2331, 2281 and 2105 were damaged from $8.3 \%$ to $15.8 \%$. 
Table 2. Resistance of red clover breeding lines and varieties to Sclerotinia crown and root rot in uninfected field, 2013-2014

\begin{tabular}{|c|c|c|c|c|c|}
\hline \multirow{2}{*}{$\begin{array}{c}\text { Breeding line/variety } \\
4 \mathrm{n}\end{array}$} & \multicolumn{2}{|c|}{ Disease severity \% } & \multirow{2}{*}{$\frac{\text { Breeding line/variety }}{2 \mathrm{n}}$} & \multicolumn{2}{|c|}{ Disease severity \% } \\
\hline & 2013 & 2014 & & 2013 & 2014 \\
\hline 1582 & 0.0 & 21.7 & 2086 & 7.5 & 9.2 \\
\hline 2095 & 5.8 & 18.3 & 2087 & 1.7 & 20.0 \\
\hline 2096 & 0.0 & 15.0 & 2088 & 3.3 & 15.8 \\
\hline 2098 & 3.3 & 21.7 & 2091 & 5.8 & 17.5 \\
\hline 2114 & 5.0 & 15.0 & 2093 & 7.5 & 29.2 \\
\hline 2190 & 0.0 & 17.5 & 2094 & 8.3 & 29.2 \\
\hline 2268 & 7.5 & 27.5 & 2101 & 5.8 & 8.3 \\
\hline 2274 & 2.5 & 18.3 & 2102 & 1.7 & 15.0 \\
\hline 2281 & 10.0 & 28.3 & 2103 & 2.5 & 11.7 \\
\hline 2282 & 1.7 & 14.2 & 2104 & 7.5 & 17.5 \\
\hline 2286 & 2.5 & 31.7 & 2105 & 8.3 & 16.7 \\
\hline 2293 & 5.0 & 27.5 & 2106 & 1.7 & 13.3 \\
\hline 2296 & 0.8 & 35.8 & 2107 & 3.3 & 18.3 \\
\hline 2298 & 5.8 & 26.7 & 2108 & 15.8 & 15.8 \\
\hline 2300 & 0.0 & 25.8 & 2177 & 5.8 & 30.0 \\
\hline 2301 & 0.0 & 28.3 & 2188 & 6.7 & 12.5 \\
\hline 2302 & 7.5 & 21.7 & 2270 & 1.7 & 18.3 \\
\hline Amos & 12.5 & 4.2 & 2295 & 3.3 & 15.0 \\
\hline Beskyd & 10.0 & 4.2 & 2297 & 13.3 & 23.3 \\
\hline Blizard & 0.8 & 21.7 & 2299 & 2.5 & 25.0 \\
\hline Cyklon & 9.2 & 15.0 & 2331 & 11.7 & 25.0 \\
\hline Divaja & 0.0 & 25.0 & 2433 & 7.5 & 20.0 \\
\hline Dolina & 5.0 & 4.2 & 2739 & 0.8 & 18.3 \\
\hline Dolly & 7.5 & 34.2 & Arija & 1.7 & 12.5 \\
\hline Ilte & 1.7 & 22.5 & Arimaičiai & 5.0 & 15.0 \\
\hline Kaive & 2.5 & 12.5 & Astra & 10.8 & 18.3 \\
\hline Kiršinai & 3.3 & 25.0 & Britta & 2.5 & 20.0 \\
\hline Kvarta & 0.0 & 2.5 & Jancis & 2.5 & 20.0 \\
\hline Nodula & 10.0 & 5.0 & Jogeva 433 & 5.8 & 12.5 \\
\hline Ostro & 5.8 & 14.2 & Jogeva 205 & 0.0 & 12.5 \\
\hline Rejista & 2.5 & 5.8 & Kamaniai & 1.7 & 25.8 \\
\hline Sadūnai & 7.5 & 25.8 & Liepsna & 9.2 & 18.3 \\
\hline Sara & 0.8 & 30.8 & Marita & 1.7 & 14.2 \\
\hline Skriveru tetra & 0.0 & 11.7 & Nemaro & 3.3 & 10.8 \\
\hline Sprint & 11.7 & 19.2 & Palma & 1.7 & 23.3 \\
\hline Tempus & 3.3 & 7.5 & Raba & 5.0 & 16.7 \\
\hline Triton & 0.8 & 37.5 & Radviliai & 0.8 & 19.2 \\
\hline Varte & 0.8 & 34.2 & Sabtoron & 7.5 & 24.2 \\
\hline Vesna & 0.0 & 6.7 & Sandis & 0.8 & 28.3 \\
\hline Vyliai & 1.7 & 20.8 & Spurt & 11.7 & 27.5 \\
\hline \multirow[t]{3}{*}{ Vulkan } & 7.5 & 19.2 & Start & 8.3 & 15.8 \\
\hline & - & - & Van & 4.2 & 18.3 \\
\hline & - & - & Vyčiai & 11.7 & 19.2 \\
\hline Min. & 0.0 & 2.5 & Min. & 0.0 & 8.3 \\
\hline Max. & 12.5 & 37.5 & Max. & 15.8 & 30.0 \\
\hline Average & 4.0 & 19.6 & Average & 5.3 & 18.5 \\
\hline $\bar{x} \pm \mathrm{S} \bar{x}$ & 0.4 & 1.0 & $\bar{x} \pm \mathrm{S} \bar{x}$ & 0.4 & 0.8 \\
\hline
\end{tabular}

The winter of 2013-2014 was also favourable for Sclerotinia crown and root rot spread. It was warm and rainy. A thin snow cover appeared in the middle of January and remained till the $8^{\text {th }}$ of February. In 2014, red clover in artificially uninfected field was much more damaged by Sclerotinia crown and root rot compared with 2013. All red clover varieties and breeding lines were damaged by Sclerotinia crown and root rot. The plants were damaged by disease from $2.5 \%$ to $37.5 \%$.
The most resistant varieties were 'Kvarta', 'Beskyd', 'Dolina', 'Amos' and 'Nodula' (damaged from 2.5\% to 5.0\%), and breeding lines Nos. 2101, 2086, 2103, 2188 and 2106 (damaged from $8.3 \%$ to $13.3 \%$ ). The least resistant varieties were 'Triton', 'Varte', 'Dolly', 'Sara' and 'Sandis' (damaged from $28.3 \%$ to $37.5 \%$ ), and breeding lines Nos. 2296, 2286, 2177, 2094 and 2093 (damaged from $29.1 \%$ to $35.8 \%$ ). 
Methods of evaluation of disease resistance in field are effective if inoculation is used at the weather conditions favourable for disease development (Jančys, Vyšniauskienè, 2002). Inoculation in the genetic red clover collection was made in the end of October in 2012, when the weather conditions were favourable for pathogen spread - it was warm and rainy.
In the artificially infected field Sclerotinia crown and root rot severity in red clover was $0-41.7 \%$ (Table 3 ). Varieties 'Divaja', 'Ilte', 'Varte', 'Arimaičiai' and 'Sara', and breeding lines Nos. 2106, 2282, 2190, 2096 and 2301 remained undamaged even after inoculation. But there were some sensitive varieties 'Beskyd' (27.1\%), 'Start' (27.1\%) and 'Nodula' (20.8\%), and breeding lines Nos.

Table 3. Resistance of red clover breeding lines and varieties to Sclerotinia crown and root rot in the infected field, 2013-2014

\begin{tabular}{|c|c|c|c|c|c|}
\hline \multirow{2}{*}{$\frac{\text { Breeding line/variety }}{4 n}$} & \multicolumn{2}{|c|}{ Disease severity \% } & \multirow{2}{*}{$\frac{\text { Breeding line/variety }}{2 \mathrm{n}}$} & \multicolumn{2}{|c|}{ Disease severity \% } \\
\hline & 2013 & 2014 & & 2013 & 2014 \\
\hline 1582 & 2.1 & 18.8 & 2086 & 29.2 & 31.3 \\
\hline 2095 & 2.1 & 33.3 & 2087 & 6.3 & 29.2 \\
\hline 2096 & 0.0 & 20.8 & 2088 & 25.0 & 22.9 \\
\hline 2098 & 2.1 & 33.3 & 2091 & 4.2 & 29.2 \\
\hline 2114 & 4.2 & 31.3 & 2093 & 16.7 & 33.3 \\
\hline 2190 & 0.0 & 33.3 & 2094 & 41.7 & 35.4 \\
\hline 2268 & 10.4 & 41.7 & 2101 & 29.2 & 27.1 \\
\hline 2274 & 6.3 & 22.9 & 2102 & 14.6 & 16.7 \\
\hline 2281 & 4.2 & 35.4 & 2103 & 12.5 & 22.9 \\
\hline 2282 & 0.0 & 31.3 & 2104 & 22.9 & 37.5 \\
\hline 2286 & 2.1 & 33.3 & 2105 & 22.9 & 20.8 \\
\hline 2293 & 10.4 & 35.4 & 2106 & 0.0 & 27.1 \\
\hline 2296 & 8.3 & 41.7 & 2107 & 16.7 & 29.2 \\
\hline 2298 & 8.3 & 43.8 & 2108 & 25.0 & 25.0 \\
\hline 2300 & 12.5 & 47.9 & 2177 & 25.0 & 45.8 \\
\hline 2301 & 0.0 & 31.3 & 2188 & 10.4 & 25.0 \\
\hline 2302 & 4.2 & 31.3 & 2270 & 16.7 & 35.4 \\
\hline Amos & 16.7 & 47.9 & 2295 & 22.9 & 25.0 \\
\hline Beskyd & 27.1 & 20.8 & 2297 & 39.6 & 27.1 \\
\hline Blizard & 10.4 & 20.8 & 2299 & 29.2 & 33.3 \\
\hline Cyklon & 10.4 & 25.0 & 2331 & 16.7 & 29.2 \\
\hline Divaja & 0.0 & 33.3 & 2433 & 10.4 & 41.7 \\
\hline Dolina & 4.2 & 20.8 & 2739 & 8.3 & 31.3 \\
\hline Dolly & 4.2 & 20.8 & Arija & 16.7 & 29.2 \\
\hline Ilte & 0.0 & 41.7 & Arimaičiai & 0.0 & 22.9 \\
\hline Kaive & 6.3 & 27.1 & Astra & 4.2 & 39.6 \\
\hline Kiršinai & 8.3 & 27.1 & Britta & 4.2 & 39.6 \\
\hline Kvarta & 12.5 & 31.3 & Jancis & 12.5 & 41.7 \\
\hline Nodula & 20.8 & 33.3 & Jogeva 433 & 12.5 & 27.1 \\
\hline Ostro & 10.4 & 27.1 & Jogeva 205 & 2.1 & 29.2 \\
\hline Rejista & 12.5 & 43.8 & Kamaniai & 4.2 & 25.0 \\
\hline Sadūnai & 8.3 & 31.3 & Liepsna & 4.2 & 31.3 \\
\hline Sara & 0.0 & 39.6 & Marita & 14.6 & 27.1 \\
\hline Skriveru tetra & 8.3 & 27.1 & Nemaro & 6.3 & 22.9 \\
\hline Sprint & 10.4 & 22.9 & Palma & 6.3 & 29.2 \\
\hline Tempus & 8.3 & 12.5 & Raba & 6.3 & 31.3 \\
\hline Triton & 14.6 & 31.3 & Radviliai & 10.4 & 25.0 \\
\hline Varte & 0.0 & 50.0 & Sabtoron & 12.5 & 29.2 \\
\hline Vesna & 2.1 & 29.2 & Sandis & 12.5 & 52.1 \\
\hline Vyliai & 2.1 & 27.1 & Spurt & 6.3 & 33.3 \\
\hline \multirow[t]{3}{*}{ Vulkan } & 16.7 & 20.8 & Start & 27.1 & 22.9 \\
\hline & - & - & Van & 8.3 & 16.7 \\
\hline & - & - & Vyčiai & 16.7 & 43.8 \\
\hline Min. & 0.0 & 0.0 & Min. & 0.0 & 16.7 \\
\hline Max. & 27.1 & 50.0 & Max. & 41.7 & 52.1 \\
\hline Average & 7.1 & 31.2 & Average & 14.7 & 30.2 \\
\hline $\bar{x} \pm \mathrm{s} \bar{x}$ & 0.8 & 1.2 & $\bar{x} \pm \mathrm{s} \bar{x}$ & 1.2 & 1.1 \\
\hline
\end{tabular}


2101, 2086, 2299, 2297 and 2094. Severity of sensitive breeding lines was from $29.1 \%$ to $41.7 \%$. In the second experimental year the severity of Sclerotinia crown and root rot was much higher compared with the first year and there were no undamaged varieties and breeding lines. The disease damaged from $12.5 \%$ to $52.1 \%$ of plants. The most resistant varieties were 'Tempus' (12.5\%) and 'Van' (16.7\%), and breeding lines Nos. 2102, 1582, 2105 and 2096. Breeding lines were damaged from $16.7 \%$ to $20.8 \%$. The most sensitive varieties were 'Rejista', 'Amos', 'Varte' and 'Sandis'. They were damaged from $43.7 \%$ to $52.1 \%$. The most sensitive breeding lines Nos. 2298, 2177 and 2300 were damages from $41.7 \%$ to $45.8 \%$.

As expected, red clover plants were much more damaged in infected field compared with uninfected. In uninfected field in 2013 disease severity was from $0 \%$ to $15.8 \%$, and in infected field from $0 \%$ to $41.7 \%$. In 2014 , in uninfected field disease severity was from $2.5 \%$ to $37.5 \%$, and in infected field from $12.5 \%$ to $52.1 \%$. The resistance of varieties and breeding lines to Sclerotinia crown and root rot and disease pressure differed between experimental years. However, there were some varieties and breeding lines which showed similar resistance to Sclerotinia crown and root rot in both years in both fields.
The most resistant varieties were 'Tempus', 'Dolina', 'Vesna', 'Nemaro' and 'Arimaičiai', and breeding lines Nos. 2096, 2106, 1582 and 2282. The most susceptible varieties were 'Vyliai', 'Sandis' and 'Varte', and breeding lines Nos. 2094, 2177, 2297 and 2299.

Treating plant seedlings with high oxalic acid concentrations is a fast, straightforward and reliable method for the selection of plants most resistant to Sclerotinia crown and root rot. This method allows executing 2-3 sampling cycles during one year by using laboratory and greenhouse methods. In the field conditions we can execute one sampling cycle during two years, if we use inoculation or during three years without inoculation if weather conditions are favourable for disease spread (Kanbe et al., 1997).

As distinct from field investigation data, in the laboratory experiment with oxalic acid tetraploid red clover plants were more sensitive compared with diploid plants (Table 4). At 5, 7.5 and $10 \mathrm{mM}$ concentrations the germination of tetraploid plants was significantly lower compared with diploid red clover plants. At 15, 20 and $30 \mathrm{mM}$ concentrations the germination of tetraploids was also lower; however, the differences were not significant.

Table 4. Percent of germinated red clover plants at different oxalic acid concentrations

\begin{tabular}{|c|c|c|c|c|c|c|c|}
\hline \multirow{3}{*}{ Ploidy } & \multirow{3}{*}{$\mathrm{n}$} & \multicolumn{6}{|c|}{ Oxalic acid concentrations $\mathrm{mM}$} \\
\hline & & 5 & 7.5 & 10 & 15 & 20 & 30 \\
\hline & & \multicolumn{6}{|c|}{ Germination $\%$} \\
\hline $2 n$ & 43 & 87.8 & 80.0 & 66.4 & 52.1 & 40.3 & 21.9 \\
\hline $4 n$ & 41 & 80.2 & 68.5 & 59.4 & 49.4 & 37.8 & 21.3 \\
\hline Average & & 84.1 & 74.0 & 63.0 & 50.8 & 39.1 & 21.6 \\
\hline $\mathrm{LSD}_{05}$ & & 4.34 & 5.28 & 5.70 & 6.21 & 5.73 & 3.61 \\
\hline
\end{tabular}

For the evaluation of red clover resistance to different oxalic acid concentrations we used the same varieties and breeding lines as in the field investigation. The breeding line 2433 showed the highest resistance in the laboratory conditions, where its germination at $5,7.5,10$ and $15 \mathrm{mM}$ oxalic acid concentrations was $99.1-92.3 \%$ and at $30 \mathrm{mM}$ concentration it was $71.1 \%$. However, in the field experiment this breeding line did not show good results of resistance to Sclerotinia crown and root rot.

Germination of varieties and breeding lines at $5 \mathrm{mM}$ concentration was $99.1-50.0 \%$, at $7.5 \mathrm{mM}$ concentration $-95.6-0 \%$, at $10 \mathrm{mM}-93.1-0 \%$, at $15 \mathrm{mM}-92.6-0 \%$, at $20 \mathrm{mM}-79.6-0 \%$ and at $30 \mathrm{mM}$ $-71.1-0 \%$. Red clover varieties were more resistant to Sclerotinia crown and root rot than breeding lines. The percent of germination of the most resistant varieties were rather stable at 5, 7.5, 10 and $15 \mathrm{mM}$ and sharp decrease occurred at 20 and $30 \mathrm{mM}$ oxalic acid concentrations (Table 5). A sharp decrease in the germination of susceptible varieties and breeding lines occurred already at $5 \mathrm{mM}$ concentration.
The most resistant varieties to oxalic acid were 'Sadūnai', 'Jancis', 'Van' and 'Radviliai'. Their germination at 5 and $7.5 \mathrm{mM}$ concentrations was $92.4-78.7 \%$, and at 20 and $30 \mathrm{mM}$ concentartion it was $71.3-37.5 \%$. Variety 'Sara' and breeding line No. 2096 can be defined as sensitive to oxalic acid, as germination of variety 'Sara' at $7.5 \mathrm{mM}$ concentration and germination of breeding line 2106 at $10 \mathrm{mM}$ oxalic acid concentration was $0 \%$. Low germination at $30 \mathrm{mM}$ oxalic acid concentration was of varieties 'Sara' $(0 \%)$, 'Sabtoron' (5.6\%), 'Raba' (12.6\%) and 'Britta' (12.7\%). These varieties also showed low resistance to Sclerotinia crown and root rot in the field conditions.

Dabkevičienè and Dabkevičius suggest that resistance of $T$. pratense wild ecotypes to Sclerotinia crown and root rot can be varying. Most of them are usually sensitive or moderately resistant to Sclerotinia crown and root rot and just a few are resistant. According to the data from their investigation, 38.5\% of wild red clover ecotypes were moderately resistant. In our investigations three wild breeding lines were 
Table 5. Germination of red clover genotypes at different oxalic acid concentrations

\begin{tabular}{|c|c|c|c|c|c|c|c|c|c|c|c|c|c|}
\hline \multirow{2}{*}{$\begin{array}{c}\begin{array}{c}\text { Breeding line/ } \\
\text { variety }\end{array} \\
4 n\end{array}$} & \multicolumn{6}{|c|}{ Oxalic acid concentration $\mathrm{mM}$} & \multirow{2}{*}{$\begin{array}{c}\text { Breeding line/ } \\
\text { variety }\end{array}$} & \multicolumn{6}{|c|}{ Oxalic acid concentration $\mathrm{mM}$} \\
\hline & 5 & 7.5 & 10 & 15 & 20 & 30 & & 5 & 7.5 & 10 & 15 & 20 & 30 \\
\hline 1582 & 93.4 & 86.7 & 58.2 & 57.4 & 48.4 & 22.7 & 2086 & 84.7 & 72.9 & 67.5 & 0.0 & 0.0 & 0.0 \\
\hline 2095 & 90.4 & 77.8 & 60.1 & 48.0 & 38.9 & 27.3 & 2087 & 76.6 & 61.9 & 58.7 & 54.8 & 37.6 & 30.2 \\
\hline 2096 & 34.6 & 0.0 & 0.0 & 0.0 & 0.0 & 0.0 & 2088 & 81.1 & 82.6 & 68.7 & 60.7 & 28.2 & 16.6 \\
\hline 2098 & 20.2 & 22.7 & 16.9 & 0.0 & 0.0 & 0.0 & 2091 & 84.1 & 77.1 & 68.8 & 0.0 & 0.0 & 0.0 \\
\hline 2114 & 58.6 & 24.1 & 20.7 & 17.2 & 13.8 & 0.0 & 2093 & 80.6 & 77.4 & 49.3 & 44.8 & 42.2 & 8.2 \\
\hline 2190 & 98.0 & 94.0 & 89.1 & 82.1 & 71.9 & 25.0 & 2094 & 89.0 & 58.6 & 41.2 & 36.1 & 26.8 & 26.8 \\
\hline 2268 & 82.2 & 81.2 & 58.9 & 51.9 & 36.9 & 19.4 & 2101 & 78.5 & 60.9 & 56.9 & 48.5 & 39.9 & 7.2 \\
\hline 2274 & 44.8 & 28.8 & 14.9 & 7.0 & 0.0 & 0.0 & 2102 & 94.4 & 87.3 & 70.6 & 48.1 & 29.0 & 26.9 \\
\hline 2281 & 79.7 & 67.7 & 46.8 & 25.8 & 12.6 & 6.4 & 2103 & 96.1 & 86.6 & 51.7 & 57.3 & 39.7 & 11.3 \\
\hline 2282 & 62.9 & 57.3 & 40.3 & 20.8 & 13.0 & 10.4 & 2104 & 95.6 & 86.5 & 79.2 & 57.2 & 49.2 & 22.9 \\
\hline 2286 & 65.2 & 55.4 & 55.7 & 43.1 & 23.1 & 9.5 & 2105 & 67.6 & 64.8 & 31.1 & 31.1 & 20.7 & 0.0 \\
\hline 2293 & 77.9 & 70.6 & 68.1 & 60.8 & 42.2 & 28.5 & 2106 & 50.0 & 45.8 & 0.0 & 0.0 & 0.0 & 0.0 \\
\hline 2296 & 57.1 & 49.0 & 26.1 & 12.3 & 7.2 & 0.0 & 2107 & 79.8 & 78.0 & 32.4 & 36.2 & 28.0 & 8.0 \\
\hline 2298 & 71.2 & 78.6 & 65.7 & 52.2 & 31.2 & 16.3 & 2108 & 77.3 & 85.3 & 73.5 & 45.7 & 36.2 & 27.3 \\
\hline 2300 & 79.5 & 69.0 & 77.5 & 52.6 & 39.9 & 16.7 & 2177 & 94.3 & 75.9 & 60.4 & 49.4 & 38.8 & 28.2 \\
\hline 2301 & 60.3 & 7.3 & 58.7 & 44.5 & 7.3 & 3.7 & 2188 & 93.6 & 80.9 & 76.6 & 42.6 & 29.8 & 17.0 \\
\hline 2302 & 81.2 & 69.4 & 63.2 & 50.0 & 41.8 & 40.0 & 2270 & 80.3 & 62.2 & 28.7 & 31.4 & 15.0 & 5.5 \\
\hline Amos & 92.0 & 81.1 & 67.7 & 65.5 & 58.6 & 25.1 & 2295 & 69.4 & 61.1 & 52.4 & 0.0 & 3.4 & 0.0 \\
\hline Beskyd & 98.7 & 87.6 & 77.6 & 70.7 & 64.4 & 19.1 & 2297 & 86.9 & 72.8 & 56.1 & 34.9 & 18.5 & 9.1 \\
\hline Blizard & 90.0 & 75.1 & 58.9 & 49.8 & 34.4 & 22.0 & 2299 & 90.0 & 80.6 & 62.5 & 53.5 & 40.6 & 15.9 \\
\hline Cyklon & 85.9 & 77.5 & 63.4 & 52.2 & 40.2 & 29.0 & 2331 & 93.4 & 70.9 & 59.4 & 50.0 & 36.1 & 24.6 \\
\hline Divaja & 55.3 & 52.6 & 37.0 & 21.1 & 10.5 & 5.3 & 2433 & 99.1 & 94.0 & 93.1 & 92.3 & 79.6 & 71.1 \\
\hline Dolina & 80.0 & 73.2 & 61.6 & 59.3 & 45.1 & 22.5 & 2739 & 88.7 & 78.5 & 64.0 & 55.3 & 49.5 & 37.8 \\
\hline Dolly & 95.1 & 86.0 & 74.9 & 62.1 & 50.2 & 37.4 & Arija & 92.6 & 93.0 & 88.7 & 81.4 & 71.0 & 20.7 \\
\hline Ilte & 89.0 & 81.9 & 68.1 & 52.0 & 40.2 & 26.4 & Arimaičiai & 97.4 & 94.2 & 90.1 & 87.1 & 69.8 & 36.2 \\
\hline Kaive & 96.7 & 92.7 & 78.2 & 62.2 & 46.5 & 32.4 & Astra & 92.9 & 92.4 & 86.4 & 77.2 & 28.1 & 18.3 \\
\hline Kiršinai & 96.3 & 75.2 & 57.4 & 45.9 & 29.4 & 15.6 & Britta & 91.9 & 85.9 & 69.3 & 52.8 & 25.9 & 12.7 \\
\hline Kvarta & 92.7 & 85.4 & 74.5 & 66.4 & 55.8 & 34.9 & Jancis & 89.1 & 85.5 & 73.4 & 64.5 & 55.6 & 37.8 \\
\hline Nodula & 91.1 & 87.5 & 79.9 & 74.5 & 64.8 & 36.7 & Jogeva 433 & 95.3 & 87.7 & 81.8 & 74.7 & 58.9 & 34.7 \\
\hline Ostro & 90.2 & 81.1 & 68.3 & 56.2 & 45.7 & 34.3 & Jogeva 205 & 89.7 & 84.3 & 76.9 & 71.9 & 60.6 & 23.0 \\
\hline Rejista & 96.6 & 90.2 & 83.5 & 77.5 & 68.3 & 36.4 & Kamaniai & 87.8 & 75.0 & 70.0 & 67.1 & 61.3 & 20.7 \\
\hline Sadūnai & 92.4 & 86.5 & 89.8 & 87.5 & 71.3 & 46.4 & Liepsna & 94.3 & 87.3 & 79.7 & 66.9 & 55.8 & 14.2 \\
\hline Sara & 71.4 & 0.0 & 0.0 & 0.0 & 0.0 & 0.0 & Marita & 91.2 & 84.7 & 74.9 & 63.3 & 52.5 & 32.6 \\
\hline Skriveru tetra & 91.2 & 80.6 & 66.3 & 55.3 & 45.1 & 33.7 & Nemaro & 95.8 & 88.2 & 77.5 & 66.6 & 49.3 & 25.4 \\
\hline Sprint & 87.1 & 78.1 & 64.9 & 54.5 & 44.8 & 33.7 & Palma & 96.7 & 89.1 & 92.0 & 83.4 & 67.4 & 29.0 \\
\hline Tempus & 84.2 & 67.8 & 56.8 & 45.1 & 38.1 & 27.8 & Raba & 73.1 & 69.0 & 49.4 & 33.6 & 16.8 & 12.6 \\
\hline Triton & 92.7 & 84.5 & 82.5 & 82.5 & 58.8 & 16.7 & Radviliai & 87.7 & 86.5 & 82.6 & 79.2 & 70.3 & 41.8 \\
\hline Varte & 84.0 & 75.8 & 63.1 & 51.2 & 40.6 & 28.7 & Sabtoron & 89.6 & 85.6 & 75.9 & 0.0 & 6.5 & 5.6 \\
\hline Vesna & 93.9 & 91.1 & 75.0 & 64.3 & 50.5 & 21.7 & Sandis & 95.1 & 87.3 & 77.1 & 66.9 & 56.3 & 31.4 \\
\hline Vyliai & 98.2 & 95.6 & 90.6 & 81.7 & 73.1 & 25.1 & Spurt & 89.3 & 75.8 & 59.8 & 50.0 & 42.6 & 29.5 \\
\hline Vulkan & 86.7 & 76.3 & 64.0 & 53.2 & 41.4 & 32.0 & Start & 85.9 & 69.2 & 59.1 & 51.4 & 42.4 & 31.2 \\
\hline - & - & - & - & - & - & - & Van & 90.9 & 78.7 & 65.2 & 59.7 & 47.8 & 37.5 \\
\hline- & - & - & - & - & - & - & Vyčiai & 98.2 & 82.4 & 81.3 & 68.6 & 60.7 & 35.7 \\
\hline Min. & 20.2 & 0.0 & 0.0 & 0.0 & 0.0 & 0.0 & Min. & 50.0 & 45.8 & 0.0 & 0.0 & 0.0 & 0.0 \\
\hline Max. & 98.7 & 95.6 & 90.6 & 87.5 & 71.3 & 46.4 & Max. & 99.1 & 94.2 & 93.1 & 92.3 & 79.6 & 71.1 \\
\hline Average & 80.2 & 68.5 & 59.4 & 49.4 & 37.8 & 21.3 & Average & 87.8 & 80.0 & 66.4 & 52.1 & 40.3 & 21.9 \\
\hline $\bar{x} \pm \mathrm{S} \bar{x}$ & 1.9 & 2.4 & 2.1 & 2.1 & 2.0 & 1.2 & $\bar{x} \pm \mathrm{S} \bar{x}$ & 1.1 & 1.2 & 1.9 & 2.2 & 2.0 & 1.3 \\
\hline
\end{tabular}

investigated. Two of them - Nos. 2177 and 2331 did not show good resistance to oxalic acid in the laboratory and to Sclerotinia crown and root rot in the field conditions. But breeding line No. 2739 can be defined as resistant, because germination of this breeding line at 5, 7.5 and $10 \mathrm{mM}$ oxalic acid concentration was $88.7-64.0 \%$, and at $30 \mathrm{mM}$ concentration it was $37.8 \%$.
Germination of Lithuanian varieties 'Sadūnai', 'Radviliai', 'Vyčiai' and 'Arimaičiai' was the highest compared with other Lithuanian varieties. It was 98.2$81.3 \%$ at $5,7.5$ and $10 \mathrm{mM}$ oxalic acid concentration and $46.4-35.7 \%$ at $30 \mathrm{mM}$ concentration. The lowest germination percentage among the Lithuanian varieties at $30 \mathrm{mM}$ oxalic acid concentration was of 'Kiršinai' 
(15.6\%) and 'Kamaniai' (20.7\%). In the field experiments, the best resistance to Sclerotinia crown and root rot was shown by the variety 'Arimaičiai'. The Lithuanian varieties 'Arimaičiai' and 'Liepsna' were previously investigated by Jančys and Vyšniauskienè (2002). He has referred to 'Arimaičiai' as resistant and 'Liepsna' as sensitive variety. In the experiment of Dabkevičienè and Dabkevičius (2005) 'Liepsna' and 'Vyliai' did not show high Sclerotinia crown and root rot resistance either.

Low oxalic acid concentrations can be insufficiently effective for the selection of varieties and breeding lines resistant to Sclerotinia crown and root rot (Rowe, Welty, 1984). Germination of varieties and breeding lines decreases with increasing concentration of oxalic acid. The higher (20 and $30 \mathrm{mM}$ ) oxalic acid concentrations enable a more precise evaluation of resistant varieties and breeding lines. In our investigations, there was no correlation between the data from the field method and laboratory method. However, there were some varieties and breeding lines which showed the same resistance in different years and at different investigation methods. Resistant varieties were 'Kaive', 'Kvarta', 'Arimaičiai', 'Skriveru tetra', 'Van', 'Ostro', 'Radviliai' and 'Jogeva 433', resistant breeding lines were Nos. 2102, 1582, 2190, 2087 and 2739.

\section{Conclusions}

1. No correlation was found between the field and laboratory susceptibility of investigated red clover genotypes to Scerotinia crown and root rot. However, there were some varieties and breeding lines which showed good resistance using both methods.

2. Tetraploid red clover plants are more resistant in the first growth year compared with diploids, but there is no difference in the second year.

3. The most resistant varieties to oxalic acid were 'Sadūnai', 'Jancis', 'Van' and 'Radviliai'.

4. The most resistant varieties to Sclerotinia crown and root rot in the field conditions were 'Tempus', 'Dolina', 'Vesna', 'Nemaro' and 'Arimaičiai' and breeding lines Nos. 2096, 2106, 1582 and 2282, and the most sensitive varieties were 'Vyliai', 'Sandis' and 'Varte' and breeding lines Nos. 2094, 2177, 2297 and 2299.

5 . The results of our investigations showed that the most resistant varieties to both Sclerotinia crown and root rot in the field conditions and to oxalic acid in the laboratory conditions were 'Kaive', 'Kvarta', 'Arimaičiai', 'Skriveru tetra', 'Van', 'Ostro', 'Radviliai' and 'Jogeva 433' and breeding lines Nos. 2102, 1582, 2190, 2087 and 2739. The most sensitive varieties were 'Sara', 'Sabtoron', 'Britta', 'Triton' and 'Astra' and breeding lines Nos. 2297, 2268, 2093, 2296, 2300 and 2298.

6. Only one wild population (No. 2739) from all investigated showed good resistance to Sclerotinia crown and root rot.
7. Among the Lithuanian varieties the best resistance to Sclerotinia crown and root rot in the field experiments was exhibited by the variety 'Arimaičiai'. Germination of this variety in oxalic acid also was very good.

Received 14092014

Accepted 10032015

\section{References}

Boller B., Schubiger F., Kölliker R., Reckenholz-Tänikon A. 2010. Red clover. Fodder Crops and Amenity Grasses, 5: 439 http://dx.doi.org/10.1007/978-1-4419-0760-8_18

Dabkevičienė G., Dabkevičius Z. 2005. Evaluation of wild red clover (Trifolium pratense L.) ecotypes and hybrid populations (Trifolium pratense L. $\times$ Trifolium diffusum Ehrh.) for clover rot resistance (Sclerotinia trifoliorum Erikss.). Biologija, 3: 54-58

Delclos B., Mousset-Declas C., Raynal G. 1997. A simple method for the evaluation of red clover (Trifolium pratense L.) resistance to Sclerotinia trifoliorum. Euphytica, 93: 173-179 http://dx.doi.org/10.1023/A:1002914002775

Dijkstra J. 1964. Inoculation with ascospores of Sclerotinia trifoliorum for detection of clover rot resistant red clover. Euphytica, 13: 314-329

Dixon G. R., Doodson J. K. 1974. Techniques for testing the resistance of red clover cultivars to Sclerotinia trifoliorum Erikss. (clover rot). Euphytica, 23: 671-679 http://dx.doi.org/10.1007/BF00022489

Gaurilčikienė I., Staniulis J. 2006. Dobilų vėžys. Lauko augalų ligos ir kenkèjai / complied by Brazauskienė I., Semaškienė R. Lithuanian Institute of Agriculture, p. 239 (in Lithuanian)

Hartung K., Piepho H. 2007. Are ordinary rating scales better than percent ratings? A statistical and "psychological" view. Euphytica, 155: 15-26 http://dx.doi.org/10.1007/s10681-006-9296-Z

Jančys Z., Vyšniauskienė R. 2002. Imitation of phytopathogenic stress with oxalate in red clover. Biologija, 48: 50-53

Kanbe M., Fujimoto F., Mizukami Y., Inami S., Fukaya K. 1997. Increase of resistance of alfalfa to Sclerotinia crown and stem rot through recurrent selection. Breeding Science, 47: $347-351$ http://dx.doi.org/10.1270/jsbbs1951.47.347

Kanbe M., Mizukami Y., Fujimoto F. 2002. Improvement of resistance to Sclerotinia crown and stem rot of alfalfa (Medicago sativa) through phenotypic recurrent selection. Japanese Agricultural Research, 36 (1): 1-5

Klimenko I., Razgulayeva N., Gau M., Okumura K., Nakaya A., Tabata S., Kozlov N. N., Isobe S. 2010. Mapping candidate QTLs related to plant persistency in red clover. Theoretical and Applied Genetics, 120 (6): 1253-1263 http://dx.doi.org/10.1007/s00122-009-1253-5

Liatukienè A., Liatukas Ž., Ruzgas V. 2012. Relationships among alfalfa resistance to Sclerotinia crown and stem rot, Sclerotinia trifoliorum and oxalic acid. African Journal of Biotechnology, 11 (72): 13690-13696 
Marum P., Smith R. P., Grau C. R. 1994. Development of procedures to identify red clover resistance to Sclerotinia trifoliorum. Euphytica, 77: 257-261 http://dx.doi.org/10.1007/BF02262639

Öhberg H., Ruth P., Bang U. 2005. Effect of ploidy and flowering type of red clover cultivars and isolate origin on severity of clover rot (Sclerotinia trifoliorum). Phytopathology, 153: 505-511 http://dx.doi.org/10.1111/j.1439-0434.2005.01003.x

Öhberg H., Ruth P., Bang U. 2008. Differential responses of red clover cultivars to Sclerotinia trifoliorum under diverse natural climatic conditions. Plant Pathology, 57: 459-466 http://dx.doi.org/10.1111/j.1365-3059.2007.01822.x

Ortega F. M., Roberts L., Clofford B. C. 1997. Rasponses of red clover (Trifolium pratense) cultivars to clover rot (Sclerotinia trofoliorum). Annals of Applied Biology, 130: 36-37

Pokorny R., Anderson, Nedelnik J., Riha P. 2003. Current state of red clover breeding for resistance in Central and Northern Europe. Czech Journal of Plant Breeding, 36: $82-85$

Poland J. A., Nelson R. J. 2011. In the eye of the beholder: the effect of rater variability and different rating scales on QTL mapping. Phytopathology, 101: 290-298 http://dx.doi.org/10.1094/PHYTO-03-10-0087

Raynal G. 1985. Observations sur le comportement varietal au champ du trefle violet vis-à-vis de la sclerotiniose at sur l'epidemiologie de la maladie. Fourrages, 101: 85-104 (in French)

Rowe D. E. 1993. Oxalic acid effects in exudates of Sclerothinia trifoliorum and S. sclerotiorum and potential use in selection. Crop Science, 33: 1146-1149 http://dx.doi. org/10.2135/cropsci1993.0011183X003300060007x

Rowe D. E., Welty R. E. 1984. Indirect selection for resistance to sclerotinia crown and stem rot on alfalfa. Canadian Journal of Plant Science, 64: 145-150 http://dx.doi.org/10.4141/cjps84-018

Sprainaitis A. 2000. White clover variety 'Nemuniai'. Zemdirbyste-Agriculture, 72: 160-169

Svirskis A. 1972. Dobilų ir liucernos selekcinès medžiagos, atsparios fuzariozei ir dobilų vėžiui atranka: disertacija ž. ù. m. kandidato laipsniui gauti. Lithuanian Institute of Agriculture, 187 p. (in Lithuanian)

Tarakanovas P., Raudonius S. 2003. Statistic analysis of agronomical research data with computer programs ANOVA, STAT, SPLIT-PLOT from packet SELEKCIJA and IRRISTAT. Lithuanian University of Agriculture, $58 \mathrm{p}$. (in Lithuanian)

Vilčinskas E., Dabkevičienè G. 2009. Qualitative and quantitative characteristics of clover (Trifolium spp.) species in the first year of growing. ZemdirbysteAgriculture, 96 (4): 170-180 (in Lithuanian)

Wallenhammar A.-C., Adolfsson E., Engström M., Henriksson M., Lundmark S., Roempke G., Stahl P. 2006. Field surveys of Fusarium root rot in organic red clover leys. Proceedings: Sustainable Grassland Productivity. Grassland Science in Europe, 11: 369-371
Williams G. H., Western J. H. 1965. The biology of Sclerotinia trifoliorum Erikss. and other species of sclerotium-forming fungi. II. The survival of sclerotia in soil. Annals of Applied Biology, 56: 261-268

http://dx.doi.org/10.1111/j.1744-7348.1965.tb01234.x

Yli-Mattila T., Kalko G., Hannukkala A., Paavanen-Huhtala S., Haka S. 2009. Prevalence, species composition, genetic variation and pathogenicity of clover rot (Sclerotinia trifoliorum) and Fusarium spp. in red clover in Finland. European Journal of Plant Pathology, 126 (1): 13-27 http://dx.doi.org/10.1007/s10658-009-9516-1

Žemaitienè P. 1962. Lietuvoje selekcionuojamų žemès ūkio augalų atsparumas grybinèms ligoms. Praktiškos kovos priemonès prieš augalų ligas, kenkèjus ir piktžoles, p. 5257 (in Lithuanian)

Бразаускене И. М. 1985. Биологические особенности Sclerotinia trifoliorum Erikss. и их использование при отборе устойчивого к этому патогену селекционного материала клевера ползучего: диссертация на соискание ученой степени кандидата биологических наук, 167 c. (in Russian) 
ISSN 1392-3196 / e-ISSN 2335-8947

Zemdirbyste-Agriculture, vol. 102, No. 2 (2015), p. 167-176

DOI $10.13080 / \mathrm{z}-\mathrm{a} .2015 .102 .022$

\title{
Raudonojo dobilo (Trifolium pratense L.) atsparumo vèžiui (Sclerotinia trifoliorum) ịvertinimas laboratorinėmis ir lauko sąlygomis
}

\author{
J. Mikaliūnienè, N. Lemežienè, V. Danytè, S. Supronienè \\ Lietuvos agrarinių ir miškų mokslų centro Žemdirbystès institutas
}

\section{Santrauka}

Raudonieji dobilai yra labai produktyvūs pirmais ir antrais naudojimo metais, tačiau vèliau jų pasėliai smarkiai išretėja arba visai žūva. Daugelyje Lietuvos vietovių pagrindinẻ liga, išretinanti raudonujų dobilų pasẻlį, yra věžys (sukèlëjas Sclerotinia trifoliorum Eriks.). Tyrimo tikslas - nustatyti raudonojo dobilo veislių ir selekcinių linijų atsparumą vėžiui laboratorinėmis ir lauko sąlygomis. Raudonojo dobilo tyrimai atlikti 2012-2014 m. Lietuvos agrarinių ir miškų mokslų centro Žemdirbystės instituto Žolių selekcijos skyriaus sejomainos laukuose. Tyrimai atlikti lauko sąlygomis esant natūraliai ir dirbtinei Sclerotinia trifoliorum Eriks. infekcijai. Raudonujų dobilų genetinejje kolekcijoje buvo tirta 43 diploidai (iš jų 20 veislių, 20 selekcinių linijų, 2 laukiniai ir 1 pusiau laukinis ekotipai) ir 41 tetraploidas (iš jų 24 veislès ir 17 selekcinių linijų). Laboratorinėmis sąlygomis panaudota oksalo rūgštis, kuri yra pagrindinis Sclerotinia spp. toksinas. Oksalo rūgšties panaudojimas sèklų dygimo metu per keletą dienų sudarè galimybę atrinkti vėžiui atsparius individus. Siekiant nustatyti atsparumą oksalo rūgščiai, tirtos 84 raudonojo dobilo veislès ir selekcinès linijos. Panaudotos įvairios oksalo rūgšties koncentracijos: $0,5,7,5,10,15$, 20 ir $30 \mathrm{mM}$. Taikant lauko ir laboratorinị metodus, galima greičiau atrinkti atsparias veisles ir selekcines linijas. Tyrimų metu nustatytos atspariausios veislès buvo 'Kaive', 'Kvarta', 'Arimaičiai', 'Skriveru tetra', 'Van', 'Ostro', 'Radviliai' bei 'Jogeva 433' ir selekcinès linijos Nr. 2102, 1582, 2190, 2087 bei 2739. Jautriausios veislès buvo 'Sara', 'Sabtoron', 'Britta', 'Triton' bei 'Astra' ir selekcinès linijos Nr. 2297, 2268, 2093, 2296, 2300 bei 2298.

Reikšminiai žodžiai: atsparumas, oksalo rūgštis, Sclerotinia trifoliorum, Trifolium pratense. 